\title{
Liming and Choice of Rootstocks as Cultural Techniques for Vines in Acid Soils"
}

\author{
W. J. CONRADIE \\ Viticuitural and Oenological Research Institute, Private Bag X5026, \\ 7600 Stellenbosch, Republic of South Africa.
}

Submitted for publication: May 1983

Accepted for publication: September 1983

\begin{abstract}
The effect of soil acidity on the performance of Chenin blanc vines grafted on 15 rootstock cultivars was determined in a pot experiment by liming a typically acid soil at $\mathrm{pH}(\mathrm{KCl}) 4,1$ (Control), to a $\mathrm{pH}$ of 5,0 (Treatment 1 ) and $\mathrm{pH} 6,0$ (Treatment 2). On average the shoot masses of vines from Treatment 1 and Treatment 2 were respectively $27 \%$ and $87 \%$ higher than those of the control. Root masses were increased by $11 \%$ and $32 \%$ respectively, indicating that the locally accepted norm of liming acid soils to a $\mathrm{pH}$ of 5,0 or to a point where exchangeable aluminium is decreased to less than $0,2 \mathrm{meq} / \mathbf{1 0 0} \mathrm{g}$ of soil, may be insufficient for most rootstocks. The beneficial effect of lime on the performance of vines could have been partly due to an improvement in the structure of the soil as indicated by lower mechanical resistances of the limed soils.

The detrimental effect of soil acidity on the performance of vines could be reduced by the correct choice of rootstocks. The cultivars 140 Ruggeri, USVIT 8-7, 110 Richter, 99 Richter and USVIT 2-1 were best suited for use on acid soils while 101-14 Mgt, 44-53 Malegue, $\mathrm{SO}_{4}$, Rupestris du Lot and USVIT 3-6 proved less suitable for the acid soil used in this investigation.
\end{abstract}

1) Presented at the 18th Congress of the Office International de la Vigne et du Vin (OIV), Cape Town 1983.

Most of the soils of the Western Cape, especially the subsoils, are acid (Saayman \& van Huyssteen, 1981). Analyses of soil samples during the past five years indicated that more than $70 \%$ (about $30000 \mathrm{ha}$ ) of the vines in this area are grown on soils with pH's (KC1) lower than 5,0. Furthermore, it was calculated that 1100 ha of acid soils are planted to vines each year.

The detrimental effect of soil acidity on the performance of plants has been illustrated for a number of crops (Kotzé \& Joubert, 1981; Hemphill \& Jackson, 1982; Kunishi, 1982; Blasl \& Bachler, 1982) but little has been done to quantify this effect for the vine. Marcelin (1974) reported that, generally speaking, the vine does not perform well at $\mathrm{pH}$ values lower than 5,0 and that stunted shoot growth as well as poor root growth may be symptoms. Delas \& Juste (1975) encountered difficulties associated with the identification of soil acidity problems by means of leaf analyses, because the leaf symptoms may not be typical while analytical data may be difficult to interpret.

There are several soil factors which may be responsible for the reduced vigour of vines on acid soils but the one generally regarded as being the most important is the presence of exchangeable aluminium in acid soils. It is known that aluminium can attain toxic concentrations at a low soil $\mathrm{pH}$ and that the exchangeable aluminium should be kept below $0,2 \mathrm{meq} / 100 \mathrm{~g}$ of soil for most plants (Reeve \& Sumner, 1970; Kotzé, 1973). Excess aluminium can be eliminated by liming, and in practice it has been found that liming to a pH of 5,0 is normally sufficient, because aluminium is decreased to non-toxic levels (Kotzé, 1973). It is, therefore, standard practice at the VORI to do a lime requirement determination on all soil samples having a pH (KC1) of lower than 5,0. The analytical procedure followed is that described by
Eksteen (1969) and uses the concept of an R-value (exchangeable $\mathrm{Ca}^{++}+\mathrm{Mg}^{++}$/exchangeable $\mathrm{H}^{+}$). For the cultivation of vines, soils are limed to an R-Value of 5,0 and in practice this ensures a $\mathrm{pH}$ of approximately 5,0 . However, apart from the aluminium toxicity problem there are several other factors which may affect the performance of vines growing in an acid environment. Marcelin (1974) mentioned manganese and copper toxicities, boron deficiency and the fact that acid soils are usually poorly supplied with calcium and magnesium. The relative importance of these factors have never been determined under local conditions. Furthermore, the effect of acidity on the physical characteristics of soil has, up to now, received virtually no attention.

One possible way of overcoming the problems associated with vines growing in an acid soil environment might be the choice of adapted rootstocks. It has been established that rootstocks may differ in their nutritional requirements (Saric, Zorzic \& Buric, 1977; Morard, Torres \& André, 1981) and this could help to make certain rootstocks less vulnerable on acid soils. Marcelin (1974) mentioned that high manganese levels were more easily tolerated on soils rich in magnesium, and this could be why the rootstock 44-53 Malegue which is known for low $\mathrm{Mg}$ absorption is the most sensitive to manganese poisoning. On the whole, however, little has been done to classify rootstocks according to their suitability for acid soils.

This investigation was undertaken firstly to identify the soil factors most detrimental to the performance of vines on acid soils; secondly, to determine the quantitive effect of acid soils on the growth of young vines, as well as their response to liming; and thirdly, to rate 15 rootstock cultivars according to their adaptability to an acid soil environment. 


\section{MATERIALS AND METHODS}

Soil: The growth medium used in this pot experiment consisted of the B21 subsoil layer from a soil classified as a Clovelly form; Southwold series (MacVicar \& Soil Survey Staff, 1977). The soil had a $\mathrm{pH}$ of 4,1 and consisted of $20,0 \%$ clay, $9,8 \%$ silt, $56,9 \%$ fine sand, $9,2 \%$ medium sand and $4,1 \%$ coarse sand. According to the method of Eksteen (1969) the lime requirement calculated for an R-value of 5 came to 6,7 tons/ha/15 $\mathrm{cm}$ soil depth. The amount of lime necessary to obtain $\mathrm{pH}$ values of 5,0 and 6,0 was determined in the laboratory by thoroughly mixing amounts of agricultural lime ranging from $0,1 \mathrm{~g}$ to $1,0 \mathrm{~g}$ with $100 \mathrm{~g}$ of dried soil in $0,1 \mathrm{~g}$ increments. Following this the samples were subjected to six wetting/drying cycles over a four week period. The $\mathrm{pH}$ values in $1 \mathrm{~N} \mathrm{KCl}$ were then determined and a calibration curve constructed for amount of lime added against $\mathrm{pH}$. From this it was determined that $0,29 \mathrm{~g}$ of lime per $100 \mathrm{~g}$ of soil was needed to attain a $\mathrm{pH}$ of 5,0 , while $0,78 \mathrm{~g}$ per $100 \mathrm{~g}$ gave a $\mathrm{pH}$ of 6,0 . This was equivalent to 5,8 and 15,6 tons of lime per hectare per $15 \mathrm{~cm}$ soil depth. The soil used for this experiment (about 8 tons) was sieved through a $6 \mathrm{~mm}$ sieve and mixed with the required amounts of lime in an industrial concrete mixer. For each treatment and for the control 45 earthenware pots of 45 litre capacity (diameter $=380 \mathrm{~mm} \times 400 \mathrm{~mm}$ high) were filled and placed in the open for two months before vines were planted.

Vines: Rooted vines of selected material from 15 rootstock cultivars were planted in the pots during October 1977 to give an experimental layout of 15 rootstocks $\times 3$ soil treatments $\times 3$ replicates. The 15 rootstock cultivars consisted of four which are well known in South Africa (99 Richter, 110 Richter, 101-14 Mgt and Ramsey), two which have been fairly widely used in the past but are currently out of favour (Rupestris du Lot and $3306 \mathrm{C}$ ), six which have not yet been fully evaluated in South Africa (140 Ruggeri, 1103 Paulsen, 1447 Paulsen, 779 Paulsen, Selection Oppenheim nr 4(SO4) and 44-53 Malegue) and three Jacquez $\times 99 \mathrm{R}$ crosses (USVIT 2-1, 3-6 and 8-7) bred locally by Orffer (1977). The vines were pruned back to two buds during the winter of 1978 and topgrafted on the new shoots to Chenin blanc in November 1978. The vines were supported on a 2-wire trellis, allowed to develop normally during the $1978 / 79$ season and pruned back to two buds in the winter of 1979. All the vines were pruned to two 2-node spurs in the winter of 1980 and sampled as indicated below during the $1980 / 81$ season.

Care of vines: The vines were watered whenever the moisture content (as indicated by tensiometers) dropped to approximately $50 \%$ of field capacity, and leaching was kept to a minimum. The vines received nitrogen fertilizer in the form of limestone ammonium nitrate $(100 \mathrm{~g} /$ vine/year added as four increments of $25 \mathrm{~g}$ each) and were sprayed regularly to combat diseases.

Sampling and analyses: After leaf fall in 1981 the one year old canes of each vine were gathered separately, dried at $60^{\circ} \mathrm{C}$ for 48 hours and the mass determined. Samples were prepared, ashed and analysed as described previously (Conradie, 1981) for $\mathrm{N}, \mathrm{P}, \mathrm{K}, \mathrm{Ca}$ and $\mathrm{Mg}$, while $\mathrm{Cu}, \mathrm{Zn}, \mathrm{Mn}$ and $\mathrm{Fe}$ were determined by means of atomic absorption spectrophotometry and B by means of the colorimetric method described by Wolf (1971). The vines were then removed from the pots, washed free of soil and air dried before separation into thick roots (diameter $>2 \mathrm{~mm}$ ), fine roots (diameter $<2 \mathrm{~mm}$ ) and trunk (consisting of rootstock trunk, scion trunk and all scion wood older than one year). The three fractions were dried at $60^{\circ} \mathrm{C}$ for 48 hours and their masses determined. Twelve pots were selected randomly (four at each of the three soil treatments) and the soil strengths determined at soil moisture contents ranging from $12,0 \%$ to $14,0 \%$. For this purpose a portable recording penetrometer as developed and described by Carter (1967) was used. The apparatus was used with a $30^{\circ}$ included angle polished steel cone with a base area of $3,22 \mathrm{~cm}^{2}$. The bulk densities of the soils from the same 12 pots were determined and they were chemically analysed for $\mathrm{pH}, \mathrm{Ca}, \mathrm{Mg}, \mathrm{K}, \mathrm{P}$ and $\mathrm{CEC}$ using standard VORI methods. Exchangeable A1 was determined in a $1 \mathrm{~N} \mathrm{KCl}$ extract by the method described by Bertsch, Alley \& Ellmore (1981).

Statistical analyses: Means were separated with the cluster analysis method developed by Scott \& Knott (1974).

\section{RESULTS AND DISCUSSION}

Soil: The chemical analyses as well as some physical measurements done on the soil before liming and at the end of the experiment, i.e. four years after liming, are given in Table 1 . Th $\mathrm{pH}$ values show that acidification has occurred in all cases. This is in accordance with the results obtained by Kotzé \& Joubert (1981) although the gravelly soil used by the above authors tended to acidify at a much faster rate. The $\mathrm{K}$-content of the control decreased when compared with the situation at the start of the experiment, possibly because of leaching. Although leaching must have occurred for the limed soils as well, this was probably compensated for by $\mathrm{K}$ from the insoluble pool becoming available at the more favourable $\mathrm{pH}$, resulting in higher $\mathrm{K}$-values for the limed soils. However, even in the case of the control soils the K-content was still higher than the accepted VORI norm of $4 \%$ of the CEC. Liming increased the Ca-content of the soils, and at the highest level of lime the $\mathrm{Mg}$-content was similar at the beginning and the end of the experiment. However, the Mg-contents were lower when compared with the situation at the beginning of the experiment for the soils from the control and intermediate lime level (Treatment 1), again pointing to the leaching of cations associated with acid soils (Marcelin, 1974). As in the case of $\mathrm{K}$ this leaching loss was compensated for in treatment 2. The A1-content of the control increased over the four year period, as could be expected from the decrease in $\mathrm{pH}$. Although the $\mathrm{pH}$ of the soil from Treatment 1 decreased to 4,6, the A1-content was still below the generally accepted figure of $0,2 \mathrm{meq} / 100 \mathrm{~g}$ (Reeve \& Sumner, 1970 ; Kotzé, 1973). Initial liming to a $\mathrm{pH}$ of 6,0 eliminated exchangeable A1 completely. The P-content was not affected by liming and although the values were low, levels like these are fairly common in the Western Cape and a 
P-deficiency for vines has not yet been substantiated. Liming did not affect the CEC of the soil in a consistent way, and Treatment 1 showed a decrease as against an increase for Treatment 2 . No explanation for the unexpected behaviour of the pH 5 soil can be offered at this stage. Although the bulk densities of the soils did not differ significantly, the limed treatments did show a tendency towards lower values. Liming had a significant effect on soil compaction as illustrated by the results for soil strengths, showing consistently lower values for limed soils. The fact that soil strength decreased with soil depth can be ascribed to varying moisture contents, ranging from about $12,0 \%$ in the top $5 \mathrm{~cm}$ to $14,0 \%$ at $25 \mathrm{~cm}$ depth.

TABLE 1

Chemical and physical analyses of soil before and four years after liming.

\begin{tabular}{|c|c|c|c|c|}
\hline \multirow{3}{*}{$\begin{array}{l}\text { Measured } \\
\text { soil } \\
\text { property }\end{array}$} & \multirow{3}{*}{$\begin{array}{l}\begin{array}{l}\text { Start of } \\
\text { experiment }\end{array} \\
\text { Before } \\
\text { liming }\end{array}$} & \multicolumn{3}{|c|}{ After 4 years } \\
\hline & & \multicolumn{3}{|c|}{ Soil Treatment } \\
\hline & & $\begin{array}{l}\text { Control } \\
\text { Initial } \\
\mathrm{pH} \text { of } 4,1\end{array}$ & $\begin{array}{l}\text { Initially } \\
\text { limed to } \\
\mathrm{pH} 5,0\end{array}$ & $\begin{array}{l}\text { Initially } \\
\text { limed to } \\
\mathrm{pH} 6,0\end{array}$ \\
\hline $\mathrm{pH}(\mathrm{KC} 1)$ & 4,1 & $3,8 \mathrm{a}^{(1)}$ & $4,6 \mathrm{~b}$ & $5,8 \mathrm{c}$ \\
\hline $\mathrm{K}(\mathrm{meq} / 100 \mathrm{~g})$ & 0,165 & 0,118 a & $0,150 \mathrm{~b}$ & $0,153 \mathrm{~b}$ \\
\hline $\mathrm{Ca}(\mathrm{meq} / 100 \mathrm{~g})$ & 0,94 & $0,76 \mathrm{a}$ & $2,26 \mathrm{~b}$ & $5,22 \mathrm{c}$ \\
\hline $\mathrm{Mg}(\mathrm{meq} / 100 \mathrm{~g})$ & 0,49 & $0,26 \mathrm{a}$ & $0,35 a b$ & $0,50 \mathrm{~b}$ \\
\hline $\mathrm{A} 1$ (meq/100g) & 0,90 & $1,03 \mathrm{a}$ & $0,15 \mathrm{~b}$ & $0,00 \mathrm{c}$ \\
\hline $\begin{array}{c}\mathrm{P}-\mathrm{Bray} \text { no. } 2 \\
(\mathrm{mg} / \mathrm{kg})\end{array}$ & 5,8 & $5,3 \mathrm{a}$ & $6,5 \mathrm{a}$ & $5,7 \mathrm{a}$ \\
\hline CEC (meq/100g) & 2,10 & $2,09 \underset{x}{a b}$ & $1,79 \mathrm{a}$ & $2,78 \mathrm{~b}$ \\
\hline $\begin{array}{l}\text { Bulk density } \\
\qquad\left(\mathrm{kg} / \mathrm{m}^{3}\right)\end{array}$ & - & $1385 \mathrm{a}$ & $1359 \mathrm{a}$ & 1307 a \\
\hline $\begin{array}{l}\text { Soil Strength } \\
\left(\mathrm{kPa} \times 10^{2}\right)\end{array}$ & & & & \\
\hline $5 \mathrm{~cm}$ soil depth & - & $7,31 \mathrm{a}$ & $7,30 \mathrm{a}$ & $5,50 \mathrm{~b}$ \\
\hline $10 \mathrm{~cm}$ soil depth & - & $6,20 \mathrm{a}$ & $5,10 \mathrm{~b}$ & $4,70 \mathrm{~b}$ \\
\hline $15 \mathrm{~cm}$ soil depth & - & $4,54 \mathrm{a}$ & $3,84 \mathrm{ab}$ & $3,40 \mathrm{~b}$ \\
\hline $20 \mathrm{~cm}$ soil depth & - & $3,51 \mathrm{a}$ & $3,14 \mathrm{ab}$ & $2,93 \mathrm{~b}$ \\
\hline $25 \mathrm{~cm}$ soil depth & - & $2,96 \mathrm{a}$ & $2,77 \mathrm{a}$ & $2,78 \mathrm{~b}$ \\
\hline
\end{tabular}

(1) Mean separation within rows by means of Duncan's multiple range test, $5 \%$ level (figures followed by similar letters do not differ significantly).
Shoot and trunk growth: Shoot and trunk masses of Chenin blanc as affected by the different rootstocks and soil acidity are shown in Table 2 . The shoot masses were low, possibly because the soil used was not the ideal growth medium for pot experiments. However, significant differences between soil treatments were found, and on average Treatment 1 showed an increase of $27 \%$ in comparison with the control, against an increase of $87 \%$ over the control for Treatment 2 . Although the $\mathrm{pH}$ of the soil from Treatment 1 was considerably lower than the accepted norm of 5,0 at the end of the experiment, the above results imply that liming to a point where exchangeable aluminium concentration is decreased to less than $0,2 \mathrm{meq} / 100 \mathrm{~g}$ of soil may still be insufficient for most rootstocks.

There were considerable differences in shoot mass between individual rootstocks with 140 Ruggeri and USVIT 8-7 performing the best on the unlimed soil while 1103 Paulsen, 44-53 Malegue, USVIT 3-6 and 101-14 Mgt showed significantly lower shoot masses than the rest. The fact that 44-53 Malegue does not perform well on acid soils has already been noted by Marcelin (1974). Liming to an initial $\mathrm{pH}$ of 5,0 had a small effect on the performance of rootstocks which did relatively well on the unlimed soil (140 Ruggeri, USVIT 8-7, 3306 C, 99 Richter and 110 Richter) but increases in shoot masses ranging from $70 \%$ to $200 \%$ were shown for the rootstocks with the poorest performances on the unlimed soil (Rupestris du Lot, 1103 Paulsen, 44-53 Malegue, USVIT 3-6 and 101-14 Mgt). Liming to an initial $\mathrm{pH}$ of 6,0 caused increased shoot masses for all rootstocks with the exception of USVIT 8-7. In this case, the fact this rootstock reacted negatively to the addition of lime could be due to trace element deficiencies induced by the lime. Visual symptoms of $\mathrm{Mn}$ and $\mathrm{Zn}$ deficiencies were detected on the leaves of Chenin blanc on this rootstock. The SO4 rootstock with an increase in shoot mass of more than $200 \%$, was obviously suited for higher $\mathrm{pH}$ conditions, which is in agreement with the fact that this cultivar is at present the most important rootstock in France (Galet, 1979) where the soils tend to be more calcareous.

TABLE 2

The effect of soil acidity on the shoot and trunk masses of Chenin blanc grafted on 15 rootstock cultivars (g dry matter/vine)

\begin{tabular}{|c|c|c|c|c|c|c|}
\hline \multirow[t]{2}{*}{ Rootstock } & \multicolumn{3}{|c|}{ Shoots } & \multicolumn{3}{|c|}{ Trunk ${ }^{(1)}$} \\
\hline & Control & $\begin{array}{l}\text { Soil initially } \\
\text { limed to } \mathrm{pH} 5,0\end{array}$ & $\begin{array}{l}\text { Soil initially } \\
\text { limed to } \mathrm{pH} 6,0\end{array}$ & Control & $\begin{array}{l}\text { Soil initially } \\
\text { limed to } \mathrm{pH} 5,0\end{array}$ & $\begin{array}{l}\text { Soil initially } \\
\text { limed to } \mathrm{pH} 6,0\end{array}$ \\
\hline USVIT 8-7 & $27,5 \mathrm{c}$ & $26,4 \mathrm{c}$ & $20,7 \mathrm{e}$ & $82,1 \mathrm{c}$ & $82,8 \mathrm{c}$ & $60,3 \mathrm{f}$ \\
\hline $3306 \mathrm{C}$ & $19,3 \mathrm{e}$ & $22,5 \mathrm{~d}$ & $28,6 \mathrm{c}$ & $89,9 \mathrm{~b}$ & $68,6 \mathrm{e}$ & $81,1 \mathrm{c}$ \\
\hline 99 Richter & $17,8 \mathrm{e}$ & $16,2 \mathrm{f}$ & $22,9 \mathrm{~d}$ & $87,7 \mathrm{~b}$ & 99,6 a & $93,5 \mathrm{~b}$ \\
\hline 110 Richter & $17,0 \mathrm{f}$ & $18,2 \mathrm{e}$ & $26,8 \mathrm{c}$ & $83,3 \mathrm{c}$ & 89,2 b & $90,1 \mathrm{~b}$ \\
\hline Ramsey & $16,9 \mathrm{f}$ & $23,6 \mathrm{~d}$ & $34,5 \mathrm{~b}$ & $51,2 \mathrm{~g}$ & $61,5 \mathrm{f}$ & $61,1 \mathrm{f}$ \\
\hline 1447 Paulsen & $15,5 \mathrm{f}$ & $22,2 \mathrm{~d}$ & $27,3 \mathrm{c}$ & $81,1 \mathrm{c}$ & $100,8 \mathrm{a}$ & $87,2 \mathrm{~b}$ \\
\hline USVIT 2-1 & $14,6 \mathrm{f}$ & $17,0 \mathrm{f}$ & $19,6 \mathrm{e}$ & 88,1 b & $81,4 \mathrm{c}$ & $78,0 \mathrm{~b}$ \\
\hline SO4 & $13,2 \mathrm{~g}$ & $10,6 \mathrm{~h}$ & $33,6 \mathrm{~b}$ & $53,3 \mathrm{~g}$ & $62,4 \mathrm{f}$ & $79,8 \mathrm{~d}$ \\
\hline 779 Paulsen & $12,5 \mathrm{~g}$ & $11,7 \mathrm{~g}$ & $26,2 \mathrm{c}$ & $69,0 \mathrm{e}$ & $92,1 \mathrm{~b}$ & $85,4 \mathrm{c}$ \\
\hline Rupestris du Lot & $12,2 \mathrm{~g}$ & $23,4 \mathrm{~d}$ & $37,6 \mathrm{a}$ & $53,6 \mathrm{~g}$ & $93,0 \mathrm{~b}$ & $75,4 \mathrm{~d}$ \\
\hline 1103 Paulsen & $10,7 \mathrm{~h}$ & $18,5 \mathrm{e}$ & $27,4 \mathrm{c}$ & $71,7 \mathrm{e}$ & $90,2 \mathrm{~b}$ & $86,7 \mathrm{c}$ \\
\hline 44-53 Malegue & $10,3 \mathrm{~h}$ & $19,1 \mathrm{e}$ & $31,6 \mathrm{~b}$ & $71,3 \mathrm{e}$ & $76,0 \mathrm{~d}$ & $76,0 \mathrm{~d}$ \\
\hline USVIT $3-6$ & $8,9 \mathrm{~h}$ & $26,8 \mathrm{c}$ & $25,4 \mathrm{c}$ & $70,2 \mathrm{e}$ & $86,4 \mathrm{c}$ & $106,2 \mathrm{a}$ \\
\hline Average & $15,6^{\mathrm{A}}$ & $19,8^{\mathrm{B}}$ & $29,2^{\mathrm{C}}$ & $72,6^{A}$ & $82,4^{\text {B }}$ & $82,9^{\text {B }}$ \\
\hline
\end{tabular}

(1) Trunk includes rootstock trunk, scion trunk and scion wood older than one year.

(2) Scott-Knott cluster analysis method, $5 \%$ level (figures followed by similar letters do not differ significantly). 
TABLE 3

Effect of soil acidity on the root mass of Chenin blanc grafted on 15 rootstock cultivars (g dry matter/vine)

\begin{tabular}{|c|c|c|c|c|c|c|c|c|c|}
\hline \multirow[t]{2}{*}{ Rootstock } & \multicolumn{3}{|c|}{ Total Mass of Roots } & \multicolumn{3}{|c|}{ Thick Roots (diameter $>2 \mathrm{~mm}$ ) } & \multicolumn{3}{|c|}{ Fine Roots (diameter $<2 \mathrm{~mm}$ ) } \\
\hline & Control & $\begin{array}{l}\text { Soil initially } \\
\text { limed to } \\
\text { pH } 5,0\end{array}$ & $\begin{array}{l}\text { Soil initially } \\
\text { limed to } \\
\mathrm{pH} 6,0\end{array}$ & Control & $\begin{array}{l}\text { Soil initially } \\
\text { limed to } \\
\text { pH } 5,0\end{array}$ & $\begin{array}{l}\text { Soil initially } \\
\text { limed to } \\
\mathrm{pH} 6,0\end{array}$ & Control & $\begin{array}{l}\text { Soil initially } \\
\text { limed to } \\
\text { pH } 5,0\end{array}$ & $\begin{array}{l}\text { Soil initially } \\
\text { limed to } \\
\mathrm{pH} 6,0\end{array}$ \\
\hline USVIT 8-7 & $201,7^{(1)} \mathrm{a}$ & $169,0 \mathrm{c}$ & $154,7 \mathrm{~d}$ & $82,7^{(1)} \mathrm{a}$ & $72,9 \mathrm{~b}$ & $48,3 \mathrm{~d}$ & $119,5^{(1)} \mathrm{b}$ & $96,7 \mathrm{~d}$ & $106,8 \mathrm{c}$ \\
\hline 140 Ruggeri & $143,0 \mathrm{e}$ & $141,0 \mathrm{e}$ & $139,7 \mathrm{e}$ & $54,4 \mathrm{c}$ & $55,4 \mathrm{c}$ & $54,9 \mathrm{c}$ & $89,0 \mathrm{~d}$ & $86,1 \mathrm{e}$ & $85,4 \mathrm{e}$ \\
\hline USVIT 2-1 & $131,0 \mathrm{f}$ & $126,2 \mathrm{f}$ & $130,0 \mathrm{f}$ & $58,7 \mathrm{c}$ & $71,3 \mathrm{~b}$ & $71,9 \mathrm{~b}$ & $72,9 \mathrm{f}$ & $54,9 \mathrm{~g}$ & $58,1 \mathrm{~g}$ \\
\hline 110 Richter & $120,0 \mathrm{~g}$ & $119,3 \mathrm{~g}$ & $139,3 \mathrm{e}$ & $47,3 \mathrm{~d}$ & $58,5 \mathrm{c}$ & $58,2 \mathrm{c}$ & $73,3 \mathrm{f}$ & $61,3 \mathrm{~g}$ & $81,8 \mathrm{e}$ \\
\hline 99 Richter & $114,7 \mathrm{~g}$ & $128,3 \mathrm{f}$ & $110,0 \mathrm{~h}$ & $30,6 \mathrm{~g}$ & $38,1 \mathrm{e}$ & $41,1 \mathrm{e}$ & 84,5 e & $90,6 \mathrm{~d}$ & $69,2 \mathrm{f}$ \\
\hline 779 Paulsen & $100,3 \mathrm{~h}$ & $100,0 \mathrm{~h}$ & $112,7 \mathrm{~g}$ & $45,1 \mathrm{~d}$ & $39,4 \mathrm{e}$ & $51,2 \mathrm{~d}$ & $55,7 \mathrm{~g}$ & $61,1 \mathrm{~g}$ & $61,7 \mathrm{~g}$ \\
\hline 1103 Paulsen & $99,7 \mathrm{~h}$ & $117,0 \mathrm{~g}$ & $122,3 \mathrm{~g}$ & $50,8 \mathrm{~d}$ & 83,5 a & $62,2 \mathrm{c}$ & $49,2 \mathrm{~h}$ & $33,8 \mathrm{i}$ & $60,6 \mathrm{~g}$ \\
\hline $3306 \mathrm{C}$ & $92,3 \mathrm{i}$ & $134,0 \mathrm{f}$ & $142,3 \mathrm{e}$ & $43,1 \mathrm{e}$ & $51,2 \mathrm{~d}$ & $32,4 \mathrm{f}$ & $49,7 \mathrm{~h}$ & $83,4 \mathrm{e}$ & $110,4 \mathrm{c}$ \\
\hline Rupestris du Lot & $91,7 \mathrm{i}$ & $122,3 \mathrm{~g}$ & $163,7 \mathrm{c}$ & 38,3 e & $47,0 \mathrm{~d}$ & $54,1 \mathrm{c}$ & $53,9 \mathrm{~h}$ & $76,2 \mathrm{f}$ & $110,3 \mathrm{c}$ \\
\hline USVIT 3-6 & $83,7 \mathrm{i}$ & $103,7 \mathrm{~h}$ & $100,0 \mathrm{~h}$ & 39,4 e & $52,4 \mathrm{~d}$ & $54,3 \mathrm{c}$ & $44,4 \mathrm{~h}$ & $51,7 \mathrm{~h}$ & $46,3 \mathrm{~h}$ \\
\hline Ramsey & $83,0 \mathrm{i}$ & $88,0 \mathrm{i}$ & $108,3 \mathrm{~h}$ & $34,7 \mathrm{f}$ & $37,1 \mathrm{e}$ & $51,2 \mathrm{~d}$ & $48,5 \mathrm{~h}$ & $51,1 \mathrm{~h}$ & $57,4 \mathrm{~g}$ \\
\hline SO4 & $76,3 \mathrm{j}$ & $93,7 \mathrm{i}$ & $176,7 \mathrm{c}$ & $27,4 \mathrm{~g}$ & $33,2 \mathrm{f}$ & $46,7 \mathrm{~d}$ & $49,7 \mathrm{~h}$ & $60,7 \mathrm{~g}$ & $130,4 \mathrm{a}$ \\
\hline 44-53 Malegue & $75,3 \mathrm{j}$ & $113,0 \mathrm{~g}$ & $140,7 \mathrm{e}$ & $24,4 \mathrm{~g}$ & $20,8 \mathrm{~h}$ & $29,9 \mathrm{~g}$ & $51,3 \mathrm{~h}$ & $92,5 \mathrm{~d}$ & $111,3 \mathrm{c}$ \\
\hline 1447 Paulsen & $72,0 \mathrm{j}$ & $74,3 \mathrm{j}$ & 89,3 i & $26,9 \mathrm{~g}$ & $29,3 \mathrm{~g}$ & $32,0 \mathrm{f}$ & $45,7 \mathrm{~h}$ & $45,5 \mathrm{~h}$ & $57,7 \mathrm{~g}$ \\
\hline 101-14 Mgt & $43,3 \mathrm{j}$ & $64,3 j$ & $186,7 \mathrm{~b}$ & $15,2 \mathrm{~h}$ & $23,8 \mathrm{~g}$ & $56,2 \mathrm{c}$ & $28,5 \mathrm{i}$ & $40,8 \mathrm{~h}$ & $130,9 \mathrm{a}$ \\
\hline Average & $101,9^{\mathrm{B}}$ & $112,9^{\mathrm{B}}$ & $134,4^{\mathrm{A}}$ & $41,2^{\mathrm{B}}$ & $47,5^{\mathrm{A}}$ & $49,6^{A}$ & $61,0^{B}$ & $65,7^{\mathrm{B}}$ & $85,2^{A}$ \\
\hline
\end{tabular}

(1) Scott-Knott cluster analysis method, $5 \%$ level (figures followed by similar letter do not differ significantly).

The trunk masses of the vines were less affected by the addition of lime, and Treatment 1 caused an average increase of only $13,5 \%$, while no further increase was found for Treatment 2 . There were differences between the reactions of individual rootstocks and, as in the case of shoots, USVIT 8-7 reacted negatively to the highest level of lime, while SO4, Rupestris du Lot, USVIT 3-6 and 101-14 Mgt showed good reaction to lime additions.

Root growth: The root masses of the vines as affected by soil acidity and different rootstocks are shown in Table 3. On an average the vines showed healthy root growth with masses comparable to that of vigorous vines grown in similar sized pots (Conradie, 1980). However, although liming did not affect root masses as much as it did shoot masses, vines from Treatment 1 still showed an increase of $10,8 \%$ for total root mass (which was not significant) when compared with the control, while Treatment 2 averaged a significant increase of $31,9 \%$ over the control. The increase in total root mass was mainly due to an increase in fine roots, and on average Treatment 2 showed $39,7 \%$ more fine roots than the control, while thick roots were only
$20,3 \%$ higher. This fact may be due to the lower soil strengths for the limed soils and/or lower aluminium toxicity.

As in the case of shoots the root growth of rootstocks differed significantly in their reaction to lime. Although the rating of the rootstocks differed somewhat when compared with that for shoot mass (Table 2), USVIT 8-7 and 140 Ruggeri again yielded the highest root mass on the unlimed soil, while 44-53 Malegue and 101-14 Mgt were again significantly lower than the rest, together with SO4 and 1447 Paulsen. The latter rootstock was placed significantly higher for shoot mass, while 1103 Paulsen showed poor shoot growth and a reasonable root growth. This made it difficult at this stage to judge the adaptability of these two rootstocks to acid soils conclusively. The commercially important Richter cultivars were similarly placed for shoot and root growth. As in the case of shoot growth, the addition of lime had a negative effect on the root growth of USVIT 8-7, while 99 Richter also reacted negatively to the highest level of lime. The rootstocks not adapted to acid soil conditions reacted highly positively to the addition of lime, with Rupestris du Lot, SO4, 44-53 Malegue

TABLE 4

Effect of soil acidity on the nutrient content of shoots from Chenin blanc grafted on 5 rootstock cultivars(1)

\begin{tabular}{|c|c|c|c|c|c|c|c|c|c|c|c|c|c|c|c|}
\hline \multirow[t]{2}{*}{ Rootstock } & \multicolumn{3}{|c|}{$N(g / 100 g)$} & \multicolumn{3}{|c|}{$P(g / 100 g)$} & \multicolumn{3}{|c|}{$\mathrm{K}(\mathrm{g} / 100 \mathrm{~g})$} & \multicolumn{3}{|c|}{$\mathrm{Ca}(\mathrm{g} / 100 \mathrm{~g})$} & \multicolumn{3}{|c|}{$\mathrm{Mg}(\mathrm{g} / 100 \mathrm{~g})$} \\
\hline & Control & $\begin{array}{l}\text { Limed } \\
\text { to } \mathrm{pH} \\
\text { of } 5,0\end{array}$ & $\begin{array}{l}\text { Limed } \\
\text { to } \mathrm{pH} \\
\text { of } 6,0\end{array}$ & Control & $\begin{array}{l}\text { Limed } \\
\text { to } \mathrm{pH} \\
\text { of } 5,0\end{array}$ & $\begin{array}{l}\text { Limed } \\
\text { to } \mathrm{pH} \\
\text { of } 6,0\end{array}$ & Control & $\begin{array}{l}\text { Limed } \\
\text { to } \mathrm{pH} \\
\text { of } 5,0\end{array}$ & $\begin{array}{l}\text { Limed } \\
\text { to } \mathrm{pH} \\
\text { of } 6,0\end{array}$ & Control & $\begin{array}{l}\text { Limed } \\
\text { to } \mathrm{pH} \\
\text { of } 5,0\end{array}$ & $\begin{array}{l}\text { Limed } \\
\text { to } \mathrm{pH} \\
\text { of } 6,0\end{array}$ & Control & $\begin{array}{l}\text { Limed } \\
\text { to } \mathrm{pH} \\
\text { of } 5,0\end{array}$ & $\begin{array}{l}\text { Limed } \\
\text { to } \mathrm{pH} \\
\text { of } 6,0\end{array}$ \\
\hline 140 Ruggeri & $0,71 \mathrm{c}$ & $0,74 \mathrm{c}$ & $0,65 \mathrm{e}$ & $0,029 \mathrm{f}$ & $0,043 \mathrm{e}$ & $0,040 \mathrm{e}$ & $0,42 \mathrm{c}$ & $0,39 \mathrm{c}$ & $0,40 \mathrm{c}$ & $0,79 \mathrm{a}$ & $0,73 \mathrm{~b}$ & $0,79 \mathrm{a}$ & $0,29 \mathrm{a}$ & $0,20 \mathrm{~d}$ & $0,23 \mathrm{~b}$ \\
\hline USVIT 8-7 & $0,72 c$ & $0,62 \mathrm{f}$ & $0,61 \mathrm{f}$ & $0,015 \mathrm{~h}$ & $0,022 \mathrm{~g}$ & $0,019 \mathrm{~h}$ & $0,23 \mathrm{~h}$ & $0,35 \mathrm{~d}$ & $0,37 \mathrm{~d}$ & $0,56 \mathrm{f}$ & $0,62 \mathrm{e}$ & $0,77 \mathrm{a}$ & $0,19 \mathrm{~d}$ & $0,17 \mathrm{~g}$ & $0,14 \mathrm{~h}$ \\
\hline $\mathrm{SO} 4$ & $0,73 \mathrm{c}$ & $0,72 \mathrm{c}$ & $0,68 d$ & $0,052 \mathrm{c}$ & $0,039 \mathrm{e}$ & $0,064 \mathrm{~b}$ & $0,36 \mathrm{~d}$ & $0,33 \mathrm{e}$ & $0,56 \mathrm{a}$ & $0,50 \mathrm{~g}$ & $0,76 \mathrm{~b}$ & $0,69 c$ & $0,14 \mathrm{~h}$ & $0,12 \mathrm{i}$ & $0,14 \mathrm{~h}$ \\
\hline 44-53 Malegue & $0,72 \mathrm{c}$ & $0,91 \mathrm{a}$ & $0,60 \mathrm{f}$ & $0,048 d$ & $0,034 \mathrm{f}$ & $0,019 \mathrm{~h}$ & $0,38 \mathrm{~d}$ & $0,46 \mathrm{~b}$ & $0,60 \mathrm{a}$ & $0,50 \mathrm{~g}$ & $0,70 \mathrm{c}$ & $0,53 \mathrm{~g}$ & $0,20 \mathrm{~d}$ & $0,20 \mathrm{~d}$ & $0,18 \mathrm{f}$ \\
\hline \multirow[t]{2}{*}{$101-14 \mathrm{Mgt}$} & $0,62 \mathrm{~d}$ & $0,65 \mathrm{~d}$ & $0,68 \mathrm{~d}$ & $0,046 \mathrm{~d}$ & $0,041 \mathrm{e}$ & $0,049 \mathrm{~d}$ & $0,28 \mathrm{~d}$ & $0,36 \mathrm{~d}$ & $0,49 \mathrm{~b}$ & $0,46 \mathrm{~h}$ & $0,61 \mathrm{e}$ & $0,54 \mathrm{~g}$ & $0,20 \mathrm{~d}$ & $0,18 \mathrm{f}$ & $0,16 \mathrm{~g}$ \\
\hline & \multicolumn{3}{|c|}{$\mathrm{Mn}(\mathrm{mg} / \mathrm{mg})$} & \multicolumn{3}{|c|}{$\mathrm{Zn}(\mathrm{mg} / \mathrm{mg})$} & \multicolumn{3}{|c|}{$\mathrm{Cu}(\mathrm{mg} / \mathrm{mg})$} & \multicolumn{3}{|c|}{$\mathrm{Fe}(\mathrm{mg} / \mathrm{mg})$} & \multicolumn{3}{|c|}{ B (mg/mg) } \\
\hline 140 Ruggeri & $49 \mathrm{~g}$ & $21,0 \mathrm{i}$ & $11,0 \mathrm{j}$ & $78 \mathrm{e}$ & $76 \mathrm{e}$ & $76 \mathrm{e}$ & $27,3 \mathrm{c}$ & $22,7 \mathrm{~d}$ & $22,7 \mathrm{~d}$ & $73 \mathrm{~d}$ & $58 \mathrm{f}$ & $48 \mathrm{~g}$ & $17 \mathrm{~b}$ & $12 \mathrm{~d}$ & $19 \mathrm{a}$ \\
\hline USVIT $8-7$ & $83 \mathrm{e}$ & $25,3 \mathrm{~h}$ & $10,0 \mathrm{j}$ & $70 \mathrm{e}$ & $56 \mathrm{f}$ & $62 \mathrm{f}$ & $21,7 \mathrm{~d}$ & $31,0 \mathrm{c}$ & $22,0 \mathrm{~d}$ & $61 \mathrm{e}$ & $65 \mathrm{e}$ & $44 \mathrm{~g}$ & $19 \mathrm{a}$ & $21 \mathrm{a}$ & $17 \mathrm{~b}$ \\
\hline $\mathrm{SO} 4$ & $142 \mathrm{~b}$ & $16,3 \mathrm{i}$ & $6,3 \mathrm{j}$ & $50 \mathrm{f}$ & $33 \mathrm{~h}$ & $49 \mathrm{f}$ & $29,0 \mathrm{c}$ & $47,7 \mathrm{a}$ & $29,3 \mathrm{c}$ & $84 \mathrm{c}$ & $51 \mathrm{~g}$ & $63 \mathrm{e}$ & $13 \mathrm{~d}$ & $15 \mathrm{c}$ & $15 \mathrm{c}$ \\
\hline 44-53 Malegue & $91 \mathrm{e}$ & $27,7 \mathrm{~h}$ & $5,0 \mathrm{j}$ & $80 \mathrm{e}$ & $141 \mathrm{a}$ & $47 \mathrm{~g}$ & $36,7 \mathrm{~b}$ & $39,0 \mathrm{~b}$ & $13,3 \mathrm{f}$ & $106 \mathrm{a}$ & $64 \mathrm{e}$ & $48 \mathrm{~g}$ & $15 \mathrm{c}$ & $15 \mathrm{c}$ & $20 \mathrm{a}$ \\
\hline $101-14 \mathrm{Mgt}$ & $107 \mathrm{~d}$ & $25,0 \mathrm{~h}$ & $19,0 \mathrm{i}$ & $124 \mathrm{~b}$ & $59 \mathrm{f}$ & $74 \mathrm{e}$ & $18,7 \mathrm{e}$ & $30,0 \mathrm{c}$ & $17,7 \mathrm{e}$ & $97 \mathrm{~b}$ & $98 \mathrm{~b}$ & $63 \mathrm{e}$ & $14 \mathrm{c}$ & $15 \mathrm{c}$ & $14 \mathrm{f}$ \\
\hline
\end{tabular}

(1) Scott-Knott cluster analysis method, $5 \%$ level (figures followed by similar letters do not differ significantly). 
and 101-14 Mgt all showing increases of more than 75\% for total root mass when Treatment 2 is compared with the control. These increases were in all cases due mainly to a larger mass of fine roots.

Nutrient content of shoots: The nutrient contents of the shoots from Chenin blanc grafted on two rootstock cultivars which did well on the acid soil (140 Ruggeri and USVIT 8-7), as well as three which did poorly on the acid soil (SO4, 44-53 Malegue and 101-14 Mgt) are shown in Table 4 . In the case of $\mathbf{N}$ there was no clear pattern discernible but with the exception of 101-14 Mgt the $\mathrm{N}$-contents of shoots from Treatment 2 were lower than that of the control. The P-contents of the shoots were low when compared with figures obtained in the Western Cape (Kleynhans, 1969) but although it has already been established for other crops that increased levels of lime increased the uptake of P (Kunishi, 1982), there were no indications of higher $\mathrm{P}$-contents for vines on the limed soils in this experiment. With the exception of 140 Ruggeri, shoots from the vines of Treatment 2 contained more $\mathrm{K}$ and $\mathrm{Ca}$ than those of the control, and with the possible exception of the K-contents of the control vines of USVIT 8-7 and 101-14 Mgt, none of the other values for $\mathrm{K}$ and $\mathrm{Ca}$ can be regarded as critically low (Kleynhans, 1969). Liming appeared to have reduced the $\mathrm{Mg}$ contents of shoots, but in contrast to the reports of Marcelin (1974) and Galet (1979), 44-53 Malegue induced as high $\mathrm{Mg}$ contents in the shoots as the other rootstocks. Although USVIT 8-7 showed visual symptoms of $\mathrm{Mn}$ and $\mathrm{Zn}$ deficiencies, the concentration of these two elements in the shoots were even lower for some of the other cultivars. Liming reduced the $\mathrm{Mn}$ contents drastically in all cases. The $\mathrm{Cu}$ and $\mathrm{Fe}$ contents showed no consistent differences between the two top and three lower ranking rootstock cultivars. The B contents of shoots from the control vines showed lower values for the three cultivars which did poorly on the acid soil, but as shoots from the limed treatments showed no consistent increases, it is unlikely that B deficiency could have been a factor on the unlimed soil. In general the results obtained for the nutrient contents of shoots gave no clear evidence as to which elements determine the poor performance of vines on acid soils. This corresponds with the conclusions of Delas \& Juste (1975).

\section{CONCLUSIONS}

In this pot experiment it has been shown that the shoot mass of young vines on a typically acid soil from the Western Cape can be doubled through effective liming, while the root mass can be increased by up to $30 \%$. Under field conditions the position may differ but it is highly unlikely that vines which find difficulty in establishing themselves on acid soils during the first few years, will ever become an economic proposition, and the grape yield may remain, in accordance with the shoot mass, as low as $50 \%$ of true potential.

In this experiment the limed soils underwent reacidification in the course of the investigation, and although this problem may be less severe under field conditions it may be worthwhile, in view of the small cost involved, to add appreciably more lime during soil preparation than the traditional amount necessary to increase the $\mathrm{pH}$ to 5,0 , or to add a few tons of lime as a routine measure annually.

Exchangeable aluminium was obviously not the only factor responsible for poor vine performance on acid soils, and soil compaction appeared to play a major detrimental role on unlimed soils. This could be one of the reasons why some rootstock cultivars were less affected by soil acidity if they could tolerate more compact soils. From the results of this experiment the cultivars 140 Ruggeri, USVIT 8-7, 110 Richter, 99 Richter and possibly USVIT 2-1 appeared to be more suited to acid soils. Cultivars least suited for acid soils were 101-14 Mgt, 44-53 Malegue, SO4, Rupestris du Lot and USVIT 3-6, while the other five cultivars (779 Paulsen, 1103 Paulsen, 1447 Paulsen, Ramsey and 3306 C) performed moderately well. However, all efforts should be made to increase soil $\mathrm{pH}$ because even the acid tolerant rootstocks benefited from liming to $\mathrm{pH} 6,0$.

\section{LITERATURE CITED}

BERTSCH, P. M., ALlEY, M. M. \& ELLMORE, T. L., 1981. Automated aluminium analysis with the aluminon method. Soil Sci. Soc. Am. J. 45, 666-667.

BLASL, Von S. \& BACHLER, W., 1982. pH-bedingte Pflanzentoxizität und Kalkwirkung. Die Bodenkultur 33, 16-40.

CARTER, L. M., 1967. Portable recording penetrometer measures soil strength profiles. Agricultural Engineering 48, 348-349.

CONRADIE, W. J., 1980. Seasonal uptake of nutrients by Chenin blanc in sand culture. I. Nitrogen. S. Afr. J. Enol. Vitic. 1, 59-65.

CONRADIE, W. J., 1981. Seasonal uptake of nutrients by Chenin blanc in sand culture. II. Phosphorus, potassium, calcium and magnesium. S. Afr. J. Enol. Vitic. 2, 7-13.

DELAS, J. \& JUSTE, C., 1975. Quelques problems poses par les sols viticoles acides. Conn. Vigne Vin 9, 67-80.

EKSTEEN, L. L., 1969. The determination of the lime requirement of soils for various crops in the Winter Rainfall Region. Fert. Soc. S. Afr. J. 2, 13-14.

GALET, P., 1979. A practical ampelography. Translated and adapted by Lucie T. Morton. Cornell University Press, Ithaca and London.

HEMPHILL, D. D. \& JACKSON, T. L., 1982. Effect of soil acidity and nitrogen on yield and elemental concentration of bush bean, carrot, and lettuce. J. Am. Soc. Hort. Sci. 107, 740-744.

KLEYNHANS, P. H., 1969. Die invloed van elf verskillende onderstok-cultivars op die makro-element status van die blare en die lote (winterhout) van Steen. Diploma for chemical technicians, task report. VORI, Private Bag X5026, 7600 Stellenbosch.

KOTZÉ, W. A. G., 1973. The influence of aluminium on plant growth. The Deciduous Fruit Grower 23, 20-22.

KOTZÉ, W. A. G. \& JOUBERT, MARLISE, 1981. Effect of liming on the growth, yield and fruit quality of apple trees in a field trial. Agrochemophysica 13, 31-35.

KUNISHI, H. M., 1982. Combined effects of lime, phosphate fertilizer, and aluminium on plant yield from an acid soil of the southeastern United States. Soil Science 134, 233-238.

MACVICAR, C. N. \& SOIL SURVEY STAFF, 1977. Soil classification - a binomial system for South Africa. Dept. Agric., Pretoria, pp 98-99.

MARCELIN, H., 1974. La vigne dans le sols du Roussilon. Progrès agric. Vitic. 91, 548-555; 570-576.

MORARD, P., TORRES, P. \& ANDRÉ, L., 1981. Influence des portegreffes sur la nutrition minerale de la vigne, (Variète Grenache). Progrès agric. Vitic. 98, 604-608. 
ORFFER, C. J., 1977. Evaluation of Jaques $\times$ Richter 99 rootstock crosses. Part I. Compatibility. Proc. S. Afr. Soc. Enol. Vitic. 144-153.

REEVE, N. G. \& SUMNER, M. E., 1970. Effects of aluminium toxicity and phosphorus fixation on crop growth on Oxisols in Natal. Soil Sci. Soc. Am. Proc. 34, 263-267.

SAAYMAN, D., \& VAN HUYSSTEEN, L., 1981. The efficiency of different methods of lime application during soil preparation. S. Afr. J. Enol. Vitic. 2, 29-36.
SARIC, M. R., ZORZIC, M. \& BURIC, D., 1977. Einfluss der Unterlage und des Reises auf die Ioneaufnahme und -verteilung. Vitis 16, 174-183.

SCOTT, A. J. \& KNOTT, M., 1974. A cluster analysis method for grouping means in the analysis of variance. Biometrics 30 , 507-512.

WOLF, B., 1971. The determination of boron in soil extracts, plant materials, composts, manures, water and nutrient solutions. Comm. Soil Sci. Plant Anal. 2, 363-374. 